\title{
Fiscal Year 2020 Annual Report
}

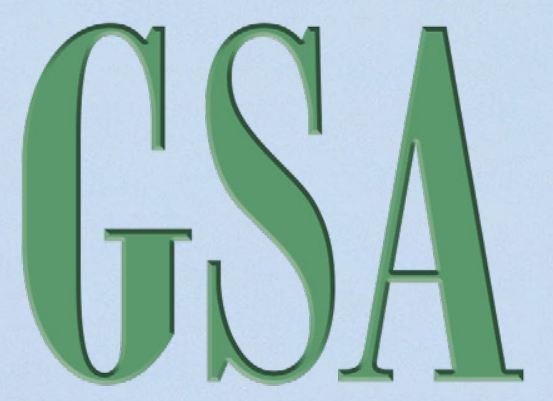

THE GEOLOGICAL SOCIETY OF AMERICA ${ }^{\circledast}$
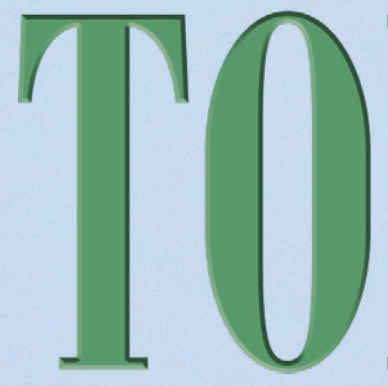

VOL. 30, NO. 1

\section{Flooding Induced by Rising Atmospheric Carbon Dioxide}

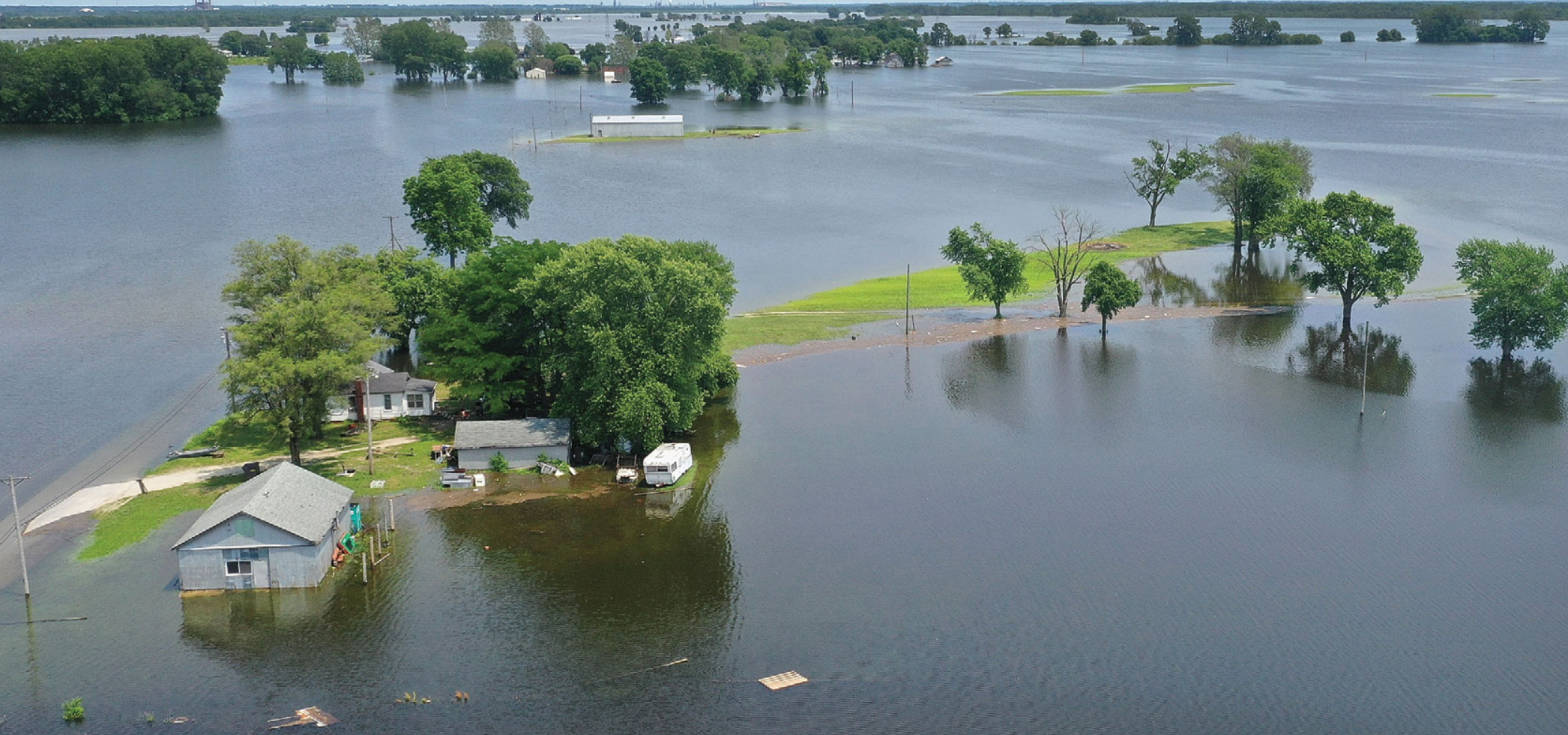




\section{Flooding Induced by Rising Atmospheric Carbon Dioxide}

Gregory J. Retallack* and Giselle D. Conde, Dept. of Earth Sciences, University of Oregon, Eugene, Oregon 97403-1272, USA

\section{ABSTRACT}

A direct consequence of rising $\mathrm{CO}_{2}$ is increasingly devastating flooding, because deciduous plants deploy fewer stomates each year as the atmospheric $\mathrm{CO}_{2}$ supplies more carbon for photosynthesis. When plants transpire less, more water runs off in streams and floods. Here we quantify this effect with highresolution observations of changing density and size of stomates of a mesic tree, Ginkgo, since 1754. The observed decline in maximum potential transpiration corresponds with rising water levels in the Mississippi River and represents a potential transpiration decline from 1829 to 2015 of $18 \mathrm{~mL} \mathrm{~s}^{-1} \mathrm{~m}^{-2}: \mathrm{a}$ reduction of $29 \%$. Rising atmospheric $\mathrm{CO}_{2}$ and declining transpiration promote flooding, which handicaps lowland cultivation and renders irrelevant insurance and zoning concepts such as the 100-year flood.

\section{INTRODUCTION}

Ongoing climatic change with rising atmospheric greenhouse gases (Yan et al., 2016) is disproportionally affecting tropical regions with sterilizing heat waves (Mora et al., 2017) and polar regions with disappearing sea ice (Kwok, 2018), but is less apparent in the American Midwest, thus allowing skepticism of global warming science (Wallace et al., 2014). Nevertheless, Midwestern cities and

Figure 1. The paradox of rising water in the Mississippi River, but little change in climate or land use: (A) maximum and mean annual water level of the Mississippi River at Hannibal, Missouri (U.S. Army Corps of Engineers, 2019); (B) mean annual precipitation $(\mathrm{mm})$ and mean annual temperature $\left({ }^{\circ} \mathrm{C}\right)$ at Hannibal (crosses) and St. Charles (solid symbol), Missouri (National Oceanographic and Atmospheric Administration, 2019a); (C) area of farmed land in United States (Sohl et al., 2016; U.S. Department of Agriculture Statistics Service, 2019: millions of hectares, open symbols) and in five Minnesota counties of St. Croix watershed (Andersen et al., 1996; thousands of hectares, closed symbols: top to bottom, Polk, St Croix, Pierce, Chisago, and Washington counties).
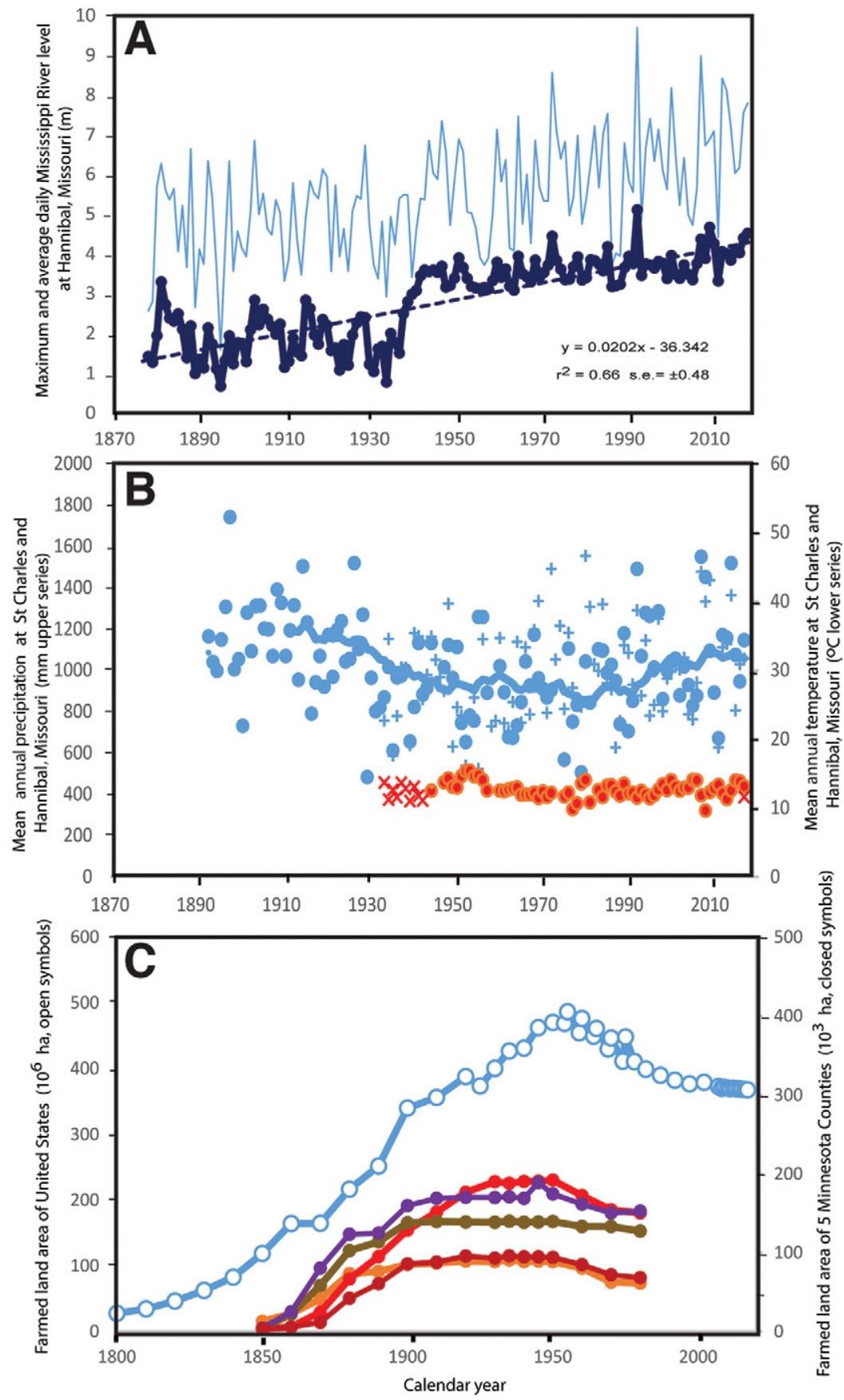

GSA Today, v. 30, https://doi.org/10.1130/GSATG427.1. Copyright 2020, The Geological Society of America. CC-BY-NC.

*gregr@uoregon.edu 
agriculture have been progressively ravaged by flooding (Fosu et al., 2018). Steadily increased floods and general level (U.S. Army Corps of Engineers, 2019) of the Mississippi River (Fig. 1A) have been independent of local climatic changes in precipitation and temperature (National Oceanographic and Atmospheric Administration, 2019a), which have remained surprisingly flat (Fig. 1B). Nor can increases in farmed areas be blamed for rising flood levels, because Midwestern cultivated acreage reached a plateau between 1900 and 1960 (Clausen, 1979; Sohl et al., 2016; Andersen et al., 1996; U.S. Department of Agriculture Statistics Service, 2019), and has declined slightly since then (Fig. 1C).

Flooding is a long-term and direct response to rising atmospheric $\mathrm{CO}_{2}$ concentrations of much greater consequence in mid-latitudes than temperature increases, and it has been observed for decades. Deciduous trees adapt to rising $\mathrm{CO}_{2}$ annually by developing fewer stomates on spring leaves, because adequate $\mathrm{CO}_{2}$ for photosynthesis can be obtained by reduced air intake (Sugano et al., 2010; Chater et al., 2015). Fewer stomates also reduce plant transpiration of water, so that more precipitation runs off in rivers and floods (Betts et al., 2007). The relationship between $\mathrm{CO}_{2}$ and stomatal density has been known for some time (Woodward, 1987), and there have been many attempts at quantifying the relationship (Royer et al., 2001; Retallack, 2001, 2009; Barclay and Wing, 2016; McElwain and Steinthorsdottir, 2017). Here we update quantification of stomatal response to atmospheric $\mathrm{CO}_{2}$ inferred from herbarium specimens of Ginkgo biloba with an unprecedented data set ranging from leaves picked in 1754 (Fig. 2) through the definitive upturn of $\mathrm{CO}_{2}$ in the early twenty-first century (Fig. 3A). Such studies have been the basis for determining $\mathrm{CO}_{2}$ levels from the distribution of stomates on fossil leaves (Retallack, 2001, 2009) and also for showing the link between greenhouse crises and flooding in deep time (Steinthorsdottir et al., 2012). A single collection of fossil or herbarium leaves determines global $\mathrm{CO}_{2}$ concentration with a resolution of weeks because the atmosphere is well mixed on such time scales, as illustrated by seasonal variation ( $\pm 4 \mathrm{ppm} \mathrm{CO}_{2}$ ) between rising values with autumn leaf shedding and drawdown by photosynthetic initiation as leaves unfurl in spring (National Oceanographic and Atmospheric Administration, 2019a). Concentrations of atmospheric $\mathrm{CO}_{2}$ are

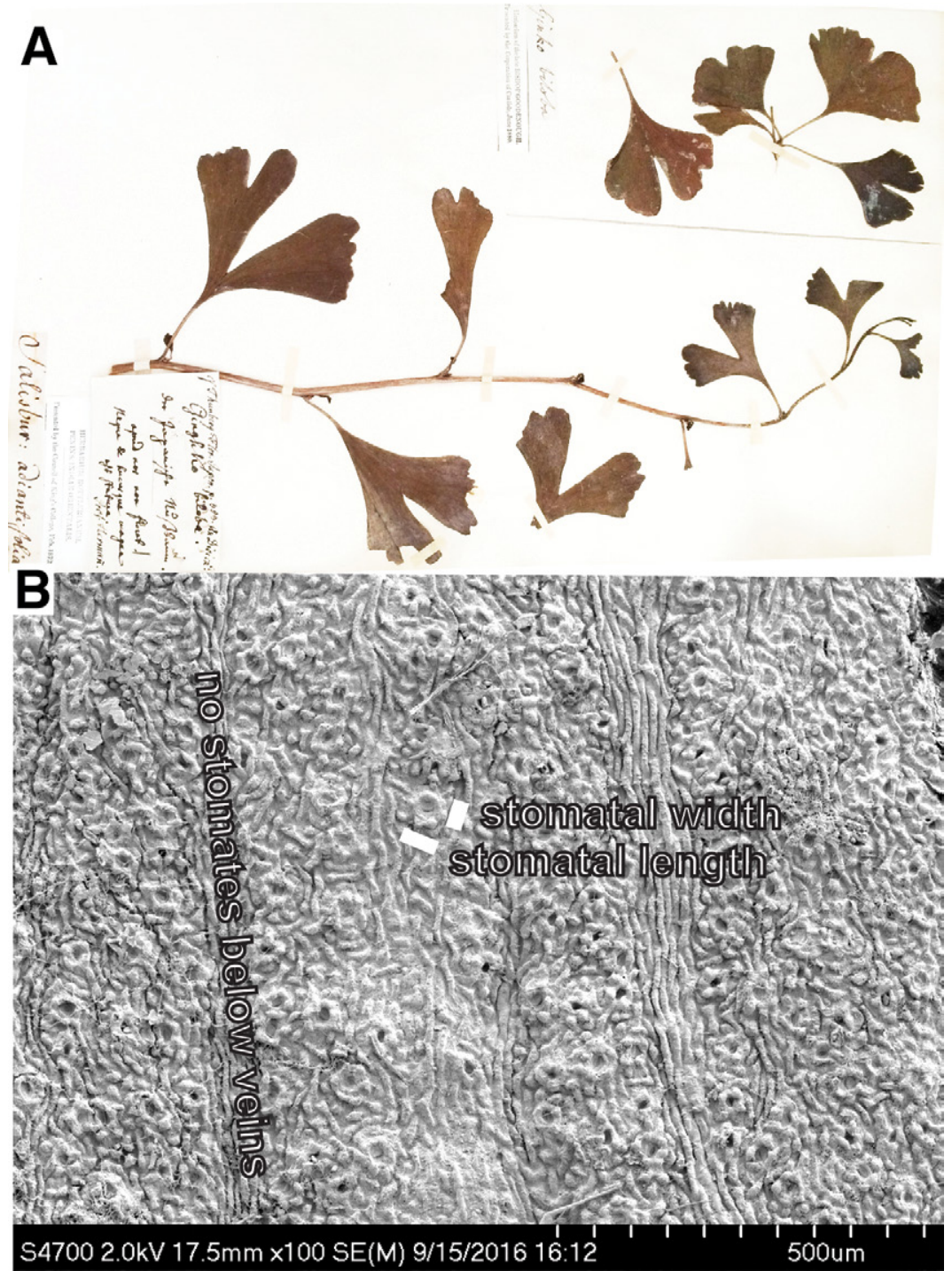

Figure 2. Stomates from leaves of Ginkgo picked in 1754 from Deshima, Japan. Large images with $\sim 600$ stomates and also non-stomatiferous areas below veins were counted to ascertain total leaf conductance. Pressed leaves from Kew Herbarium and scanning electron microscopy image courtesy of Chrissie Pritchard.

sensed by stomatal ion channels, which direct gene expression for stomatal density in the developing leaf for that year (Sugano et al., 2010; Chater et al., 2015). In deciduous plants like Ginkgo and oak (Quercus), stomatal index reflects spring time $\mathrm{CO}_{2}$ for the year in which that leaf formed. Ginkgo has been a favorite for such studies because of its unusually long fossil record, and so has the highest quality data (Barclay and Wing, 2016; Retallack and Conde, 2020). Comparable records have been obtained from oak (Quercus) and many other species of leaves (Lammertsma et al., 2011). The relationship between stomatal density and atmospheric $\mathrm{CO}_{2}$ varies with different species, but Quercus and Ginkgo have a similar response (Fig. 3B-3C).

\section{MATERIALS AND METHODS}

We used scanning electron microscopy (SEM) images from herbarium specimens of Ginkgo biloba (Retallack and Conde, 2020) to refine a time series of historic stomatal parameters (Retallack, 2009), now extended back to 1754 with specimens in Kew Herbarium picked in Deshima, Japan, and forward with specimens picked during the dramatic upswing in $\mathrm{CO}_{2}$ over the past decade (Fig. 2). Stomatal papillae may obscure subsidiary cell walls in cuticle preparations (Barclay and Wing, 2016), but are clear in SEM images (Fig. 2B). Our method counted images with $\sim 600$ cells and 60 stomates in both stomatiferous and astomatic areas as a proxy for total leaf conductance. Counting smaller areas of cuticle with only 

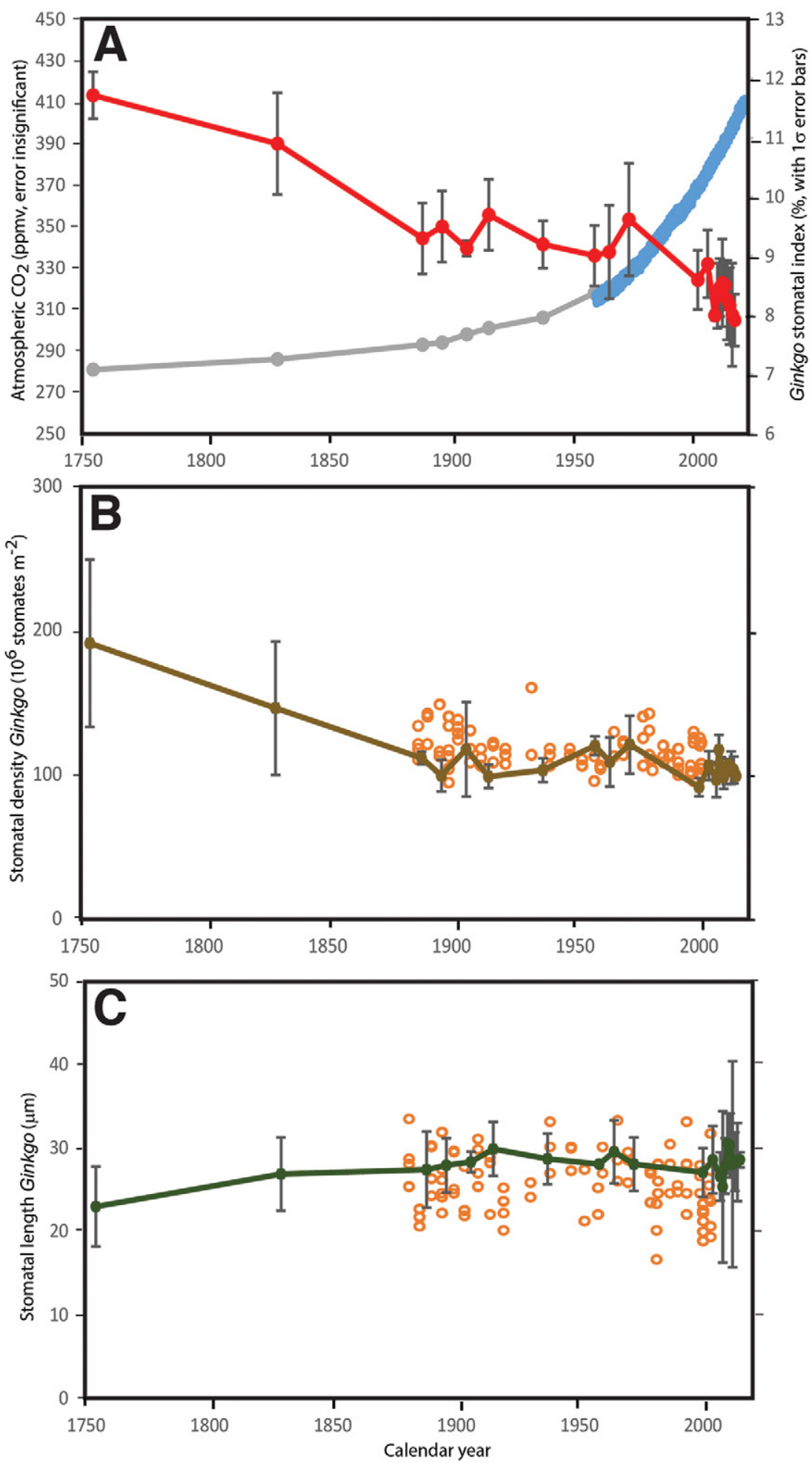

Figure 3. Changes in Ginkgo stomatal parameters since 1754: (A) observed (National Oceanographic and Atmospheric Administration, 2019b) and inferred from ice cores (Lüthi, et al., 2008: before 1955) atmospheric $\mathrm{CO}_{2}$, with insignificant error, and declining

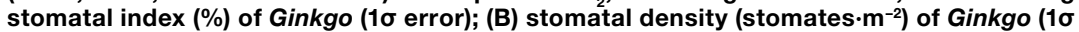

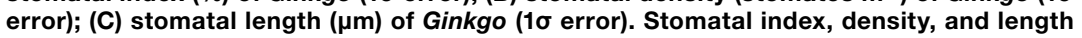
were all measured from scanning electron microscopy images of herbarium specimens (Retallack and Conde, 2020). Comparable data scatter in panels (B) and (C) are for Quercus laurifolia in Florida, from Lammertsma et al. (2011).
5-16 stomates (Barclay and Wing, 2016) gives unacceptable systematic errors of stomatal index: $\sim 20 \%$ depending on whether four or five stomates are accidently in the image. Stomatal bands are distinct from astomatic areas below veins, but we counted both stomatal and subvenal areas to capture total leaf conductance (Fig. 2B).

The current stomatal index $\mathrm{CO}_{2}$ paleobarometer (Retallack and Conde, 2020) is based on atmospheric $\mathrm{CO}_{2}(\mathrm{C}$ in ppm) from observations (National Oceanographic and Atmospheric Administration, 2019b) and ice cores (Lüthi et al., 2008) together with stomatal index ( $I$ in \% from Equation 1$)$ from microscopic imaging of herbarium specimens in which number of stomates $(n)$ and number of epidermal cells $\left(n_{e}\right)$ in the same area are counted. This inverse relationship (Equation 2) has an algebraically simplified equivalent (Equation 3) between Gingko stomatal index ( $I$ in \%) and atmospheric $\mathrm{CO}_{2}$ (C in ppm). Standard deviations $(1 \sigma)$ of $\mathrm{CO}_{2}$ concentration (in ppm) were calculated by Gaussian error propagation. Maximum potential transpiration $\left(g_{\text {wmax }}\right.$ in $\left.\mathrm{mol} \cdot \mathrm{m}^{-2} \mathrm{~s}^{-1}\right)$ can be calculated using Equation 4 (Wolfram Alpha, 2019; Franks et al., 2014) with additional measurements of stomatal pore length $(l$, in $\mathrm{m})$, width $(w$, in $\mathrm{m})$, and density of stomates $\left(D\right.$, as number per $\left.\mathrm{m}^{2}\right)$, as well as physical constants (Cussler, 1997) of diffusivity of water vapor in air $\left(d=0.0000282 \mathrm{~m}^{-2} \cdot \mathrm{s}^{-1}\right)$ and molar volume of air $(v=0.0224$ $\mathrm{m}^{-3} \cdot \mathrm{mol}^{-1}$ ), and 0.6 area correction factor for Ginkgo biloba stomatal anatomy (Franks et al., 2014). Diffusivity and molar volumes of vapor and liquid are all at $25^{\circ} \mathrm{C}$ and $1 \mathrm{~atm}$. All measurements of Ginkgo biloba stomatal density, length, and width are included in the GSA supplemental material.

$$
\begin{gathered}
I=100 \times \frac{n_{s}}{n_{s}+n_{e}} \\
C=239.7+\frac{1}{2.75255 \times 10^{-7} \times I^{4.79}} \\
C=239.7+3,633,000 \times I^{-4.79} \\
g_{\text {wmax }}=\frac{\frac{d}{v} \cdot D \cdot 0.6 \pi\left(\frac{l}{2}\right)^{2}}{\frac{w}{2}+\left(\frac{\pi}{2}\right) \sqrt{\frac{0.6 \pi\left(\frac{l}{2}\right)^{2}}{\pi}}}
\end{gathered}
$$

${ }^{1}$ Supplemental Material: Stomatal data for Ginkgo biloba. Please visit https://doi.org/10.1130/GSAT.S.12678941 to access the supplemental material, and contact editing@geosociety.org with any questions. 
Our data on plant stomatal response to a well-mixed atmosphere reflects global $\mathrm{CO}_{2}$, but our assessment of flooding response was limited to upper Mississippi River data derived from public databases (U.S. Army Corps of Engineers, 2019). This region was also chosen because of available data on climate change (National Oceanographic and Atmospheric Administration, 2019a) and land use (Clausen, 1979; Sohl et al., 2016; Andersen et al., 1996; U.S. Department of Agriculture Statistics Service, 2019).

\section{RESULTS}

Our study is based on measurements of stomatal parameters of herbarium specimens of Ginkgo biloba extending back to 1754 (Fig. 2). Ginkgo stomatal proxies are similar to those established for Quercus and other plants (Royer et al., 2001; Lammertsma et al., 2011; Franks et al., 2014), and the Ginkgo stomatal record is among the best known (Barclay and Wing, 2016; Retallack and Conde, 2020). Measures of stomatal length and width can be used to calculate maximum pore area and volume (Franks et al., 2014) and infer water conductance from leaves using the physics of diffusion through pores (Cussler, 1997). Our records show a secular decline in stomatal index, or percent stomates versus epidermal cells (Equation 1), of Ginkgo with increasing atmospheric $\mathrm{CO}_{2}$ as measured since 1955 on Mauna Loa (National Oceanographic and Atmospheric Organization, 2019b) with a base line provided by earlier data (Lüthi et al., 2008) from ice cores (Fig. 3A). The change in Ginkgo stomatal index over the past 265 years was due more to changes in stomatal density (Fig. 3B) than to stomatal size (Fig. 3C), and our high-precision data from Ginkgo are supported by less-accurate data from Quercus (Lammertsma et al., 2011). There is evidence from fossils that stomatal size also changes when atmospheric $\mathrm{CO}_{2}$ is very high (Retallack, 2009; Franks and Beerling, 2009), but that threshold was not reached in our observations. Stomatal size also changes significantly with gene ploidy levels (McElwain and Steinthorsdottir, 2017), but such jumps were not seen in our data either.

The decline in transpiration for Ginkgo 1829-2015 has been dramatic (Fig. 4A): 0.98 $\mathrm{mol} \mathrm{s}-1 \mathrm{~m}^{-2}$. This is $73 \mathrm{~L} \mathrm{~s}^{-1} \mathrm{~m}^{-2}$ of water vapor, or $18 \mathrm{~mL} \mathrm{~s}^{-1} \mathrm{~m}^{-2}$ liquid water, and a reduction by $29 \%$. This substantial decline is a maximal value realized for only a part of the day in favorable seasons and illumination, but if biorhythms of the plants remained comparable, as seems reasonable for regions such as the American Midwest with relatively stable climate (Fig. 1B), a comparable decline in transpiration is likely. Our result also assumes that the stomatal response of Ginkgo is comparable with that of dominant Midwestern plants such as Quercus, because both show comparable slopes in stomatal $\mathrm{CO}_{2}$ response over changing historic $\mathrm{CO}_{2}$ concentrations (Royer et al., 2001). Furthermore, comparable data from Quercus laurifolia from a Florida swamp (Lammertsma et al., 2011) straddles our data (Figs. 3B-3C, 4A) but with greater variance due to smaller cell counts. Quercus is a dominant plant throughout much of the northern hemisphere (Manos et al., 1999). The central Mississippi River had estimated summer monthly evapotranspiration $(\mathrm{Mu}$ et al., 2013) of $90 \mathrm{~mm}$ by 2010. The transpiration decline $1829-2015$ is $29 \%$, for a decline since
1829 of $30 \mathrm{~mm}$ evapotranspiration, and as much added to runoff.

\section{RISING WATERS}

Records of Mississippi River levels at Hannibal, Missouri (U.S. Army Corps of Engineers, 2019), go back to 1888, and since that time, mean annual river levels have risen in proportion to the decline in maximum transpiration of Ginkgo (Fig. 4B). Flood levels also increased over time, but their severity has been erratic (Fig. 1A). Other factors promoting flooding include reduced transpiration from replacement of trees with grasses (Alton et al., 2009; Morton et al., 2015), observed in pollen records (Sohl et al., 2016), and maintenance of hard surfaces such as roads and parking lots to service continuously developed acreages (U.S. Department
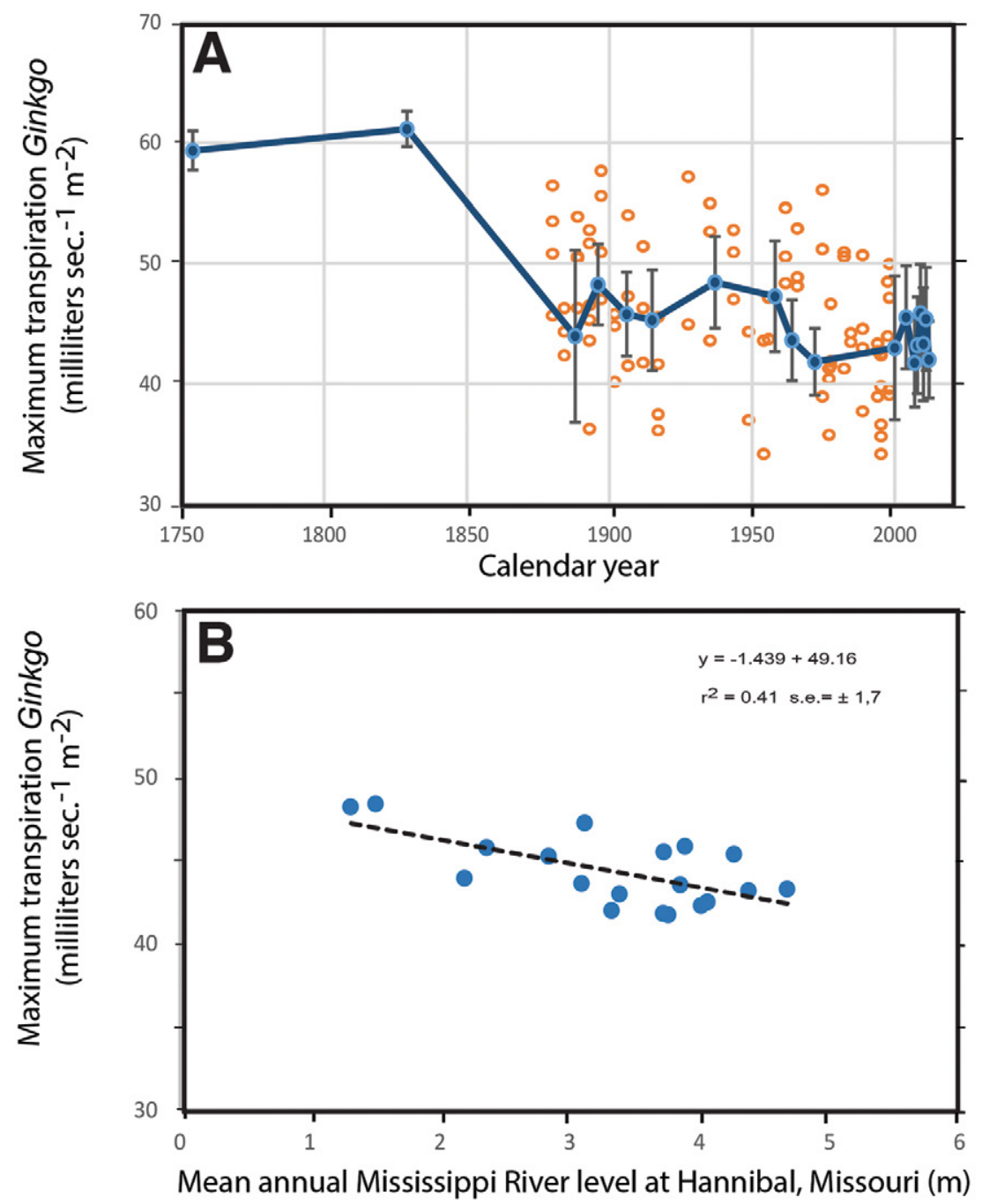

Figure 4. Changes in Ginkgo transpiration since 1754: (A) reduction in maximum stomatal

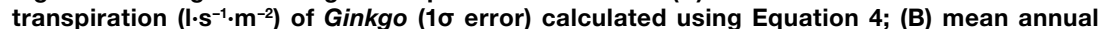
level of Mississippi River at Hannibal, Missouri, $(m)$ as a function of maximum stomatal transpiration $\left(1 \cdot \mathrm{s}^{-1} \cdot \mathrm{m}^{-2}\right)$ of Ginkgo. Comparable data in panel (A) from Quercus laurifolia in Florida is from Lammertsma et al. (2011). 
of Agriculture Statistics Service, 2019). In this regime of rising river and flood levels, planning for the 100-year or other flood recurrence levels is vain, and non-stationary flood prediction is needed (Vogel et al., 2011). At Hannibal, Missouri, annual average levels of the river can be expected to rise $2 \mathrm{~cm}$ per year for the foreseeable future (Fig. 1A), even if climate does not finally become significantly more humid, as expected with rise in atmospheric temperature (Retallack and Conde, 2020). Declining transpiration as a direct response to rising atmospheric $\mathrm{CO}_{2}$ is an underappreciated factor in flood prediction (Betts et al., 2007).

\section{ACKNOWLEDGMENTS}

We thank Greg Bothun, Dan Gavin, and Pat Bartlein for stimulating discussions. Jonathan Wynn, Joshua Roering, and Edward Davis proffered mathematical advice. Chrissie Prychid and Nicola Kuhn provided scanning electron microscopy images of Ginkgo leaves of the Kew Herbarium picked in 1754 in Japan. Arne Arneberg provided leaf fragments from the Swedish Natural History Museum picked in 1829 from "Hortus Botanicus Augustinus," Amsterdam. Hugo de Boer provided raw data on oak stomatal index from Florida published by Lammertsma et al. (2011). Sarena Campbell, John Donovan, and Julie Chouinard aided with scanning electron microscopy.

\section{REFERENCES CITED}

Alton, P., Fisher, R., Los, S., and Williams, M., 2009, Simulations of global evapotranspiration using semiempirical and mechanistic schemes of plant hydrology: Global Biogeochemical Cycles, v. 23, GB4023, https://doi.org/10.1029/2009GB003540.

Andersen, O., Crow, T.R., and Leitz, S.M., 1996, Transformation of a landscape in the upper midwest, USA: The history of the lower St. Croix River valley, 1830 to present: Landscape and Urban Planning, v. 35, p. 247-267, https://doi.org/ 10.1016/S0169-2046(96)00304-0.

Barclay, R.S., and Wing, S.L., 2016, Improving the Ginkgo $\mathrm{CO}_{2}$ barometer: Implications for the early Cenozoic atmosphere: Earth and Planetary Science Letters, v. 439, p. 158-171, https://doi.org/ 10.1016/j.epsl.2016.01.012.

Betts, R.A., Boucher, O., Collins, M., Cox, P.M., Falloon, P.D., Gedney, N., Hemming, D.L., Huntingford, C., Jones, C.D., Sexton, D.M.H., and Webb, M.J., 2007, Projected increase in continental runoff due to plant responses to increasing carbon dioxide: Nature, v. 448, p. 1037-1041, https://doi.org/ 10.1038/nature06045.

Chater, C., Peng, K., Movahedi, M., Dunn, J.A., Walker, H.J., Liang, Y.K., McLachlan, D.H., Casson, S., Isner, J.C., Wilson, I., and Neill, S.J., 2015, Elevated $\mathrm{CO}_{2}$-induced responses in stomata require $\mathrm{ABA}$ and $\mathrm{ABA}$ signaling: Current Biology, v. 25, p. 2709-2716, https://doi.org/ 10.1016/j.cub.2015.09.013.

Clausen, M., 1979, Forests in the long sweep of American history: Science, v. 204, p. 1168-1174, https://doi.org/10.1126/science.204.4398.1168.
Cussler, E.L., 1997, Diffusion: Mass Transfer in Fluid Systems: Cambridge, UK, Cambridge University Press, $580 \mathrm{p}$.

Fosu, B., Wang, S., and Pegion, K., 2018, Synoptic and climate attributions of the December 2015 extreme flooding in Missouri, USA: Water, v. 10, p. 350, https://doi.org/10.3390/w10040350.

Franks, P.J., and Beerling, D.J., 2009, Maximum leaf conductance driven by $\mathrm{CO}_{2}$ effects on stomatal size and density over geologic time: Proceedings of the National Academy of Sciences of the United States of America, v. 106, p. 10,343-10,347, https:// doi.org/10.1073/pnas.0904209106.

Franks, P.J., Royer, D.L., Beerling, D.J., Van de Water, P.K., Cantrill, D.J., Barbour, M.M., and Berry, J.A., 2014, New constraints on atmospheric $\mathrm{CO}_{2}$ concentration for the Phanerozoic: Geophysical Research Letters, v. 41, p. 46854694, https://doi.org/10.1002/2014GL060457.

Kwok, R., 2018, Arctic sea ice thickness, volume, and multiyear ice coverage: Losses and coupled variability (1958-2018): Environmental Research Letters, v. 13, 105005, https://doi.org/10.1088/ 1748-9326/aae3ec.

Lammertsma, E.I., de Boer, H.J., Dekker, S.C., Dilcher, D.L., Lotter, A.F., and Wagner-Cremer, F., 2011, Global $\mathrm{CO}_{2}$ rise leads to reduced maximum stomatal conductance in Florida vegetation: Proceedings of the National Academy of Sciences of the United States of America, v. 108, p. 40354040, https://doi.org/10.1073/pnas.1100371108.

Lüthi, D., Le Floch, M., Bereiter, B., Blunier, T., Barnola, J.-M., Siegenthaler, U., Raynaud, D., Jouzel, J., Fischer, H., Kawamura, K., and Stocker, T.F., 2008, High-resolution carbon dioxide concentration record 650,000-800,000 years before present: Nature, v. 453, p. 379-382, https://doi.org/10.1038/ nature 06949.

Manos, P.S., Doyle, J.J., and Nixon, K.C., 1999, Phylogeny, biogeography, and processes of molecular differentiation in Quercus subgenus Quercus (Fagaceae): Molecular Phylogenetics and Evolution, v. 12 , p. 333-349, https://doi.org/10.1006/ mpev.1999.0614

McElwain, J.C., and Steinthorsdottir, M., 2017, Paleoecology, ploidy, paleoatmospheric composition, and developmental biology: A review of the multiple uses of fossil stomata: Plant Physiology, v. 174, p. 650-664, https://doi.org/10.1104/pp.17.00204.

Mora, C., Dousset, B., Caldwell, I.R., Powell, F.E., Geronimo, R.C., Bielecki, C.R., Counsell, C.W.W., Dietrich, B.S., Johnston, E.T., Louis, L.V., Lucas, M.P., McKenzie, M.M., Shea, A.G., Tseng, H., Giambelluca, T.W., Leon, L.R., Hawkins, E., and Trauernicht, C., 2017, Global risk of deadly heat: Nature Climate Change, v. 7, p. 501-506, https:// doi.org/10.1038/nclimate3322.

Morton, L.W., Hobbs, J., Arbuckle, J.G., and Loy, A., 2015, Upper Midwest climate variations: Farmer responses to excess water risks: Journal of Environmental Quality, v. 44, p. 810-822, https://doi.org/10.2134/jeq2014.08.0352.

Mu, Q., Zhao, M., and Running, S.W., 2013, MODIS global terrestrial evapotranspiration (ET) product: NASA document https://modis-land.gsfc.nasa.gov/ pdf/MOD16ATBD.pdf (accessed 26 Aug. 2019).

National Oceanographic and Atmospheric Administration, 2019a, Climatic data online for Hannibal water works (USC00233601) and St Charles (USC00237397), Missouri: https://www.noaa.gov (accessed 4 Apr. 2019).
National Oceanographic and Atmospheric Administration, 2019b, $\mathrm{CO}_{2}$ observed on Mauna Loa: https://www.esrl.noaa.gov/gmd/ccgg/trends/ (accessed 5 Mar. 2019).

Retallack, G.J., 2001, A 300-million-year record of atmospheric carbon dioxide from fossil plant cuticles: Nature, v. 411, p. 287-290, https://doi.org/ 10.1038/35077041.

Retallack, G.J., 2009, Greenhouse crises of the past 300 million years: Geological Society of America Bulletin, v. 121, p. 1441-1455, https://doi.org/ 10.1130/B26341.1.

Retallack, G.J., and Conde, G.D., 2020, Deep time perspective on rising atmospheric $\mathrm{CO}_{2}$ : Global and Planetary Change, v. 189, 103177, https://doi .org/10.1016/j.gloplacha.2020.103177.

Royer, D.L., Berner, R.A., and Beerling, D.J., 2001, Phanerozoic atmospheric $\mathrm{CO}_{2}$ change: Evaluating geochemical and paleobiological approaches: Earth-Science Reviews, v. 54, p. 349-392, https:// doi.org/10.1016/S0012-8252(00)00042-8.

Sohl, T., Reker, R., Bouchard, M., Sayler, K., Dornbierer, K., Wika, S., Qunzer, R., and Friesz, A., 2016, Modeled historical land use and land cover for the conterminous United States: Journal of Land Use Science, v. 11, p. 476-499, https://doi.org/ 10.1080/1747423X.2016.1147619.

Steinthorsdottir, M., Woodward, F.I., Surlyk, F., and McElwain, J.C., 2012, Deep-time evidence of a link between elevated $\mathrm{CO}_{2}$ concentrations and perturbations in the hydrological cycle via drop in plant transpiration: Geology, v. 40 , p. $815-818$, https://doi.org/10.1130/G33334.1.

Sugano, S.S., Shimada, T., Imai, Y., Okawa, K., Tamai, A., Mori, M., and Hara-Nishimura, I., 2010, Stomagen positively regulates stomatal density in Arabidopsis: Nature, v. 463, p. 241-244, https://doi.org/10.1038/nature08682.

U.S. Army Corps of Engineers, 2019, Mississippi River at Hannibal, Missouri, http://rivergages .mvr.usace.army.mil (accessed 2 Apr. 2019).

U.S. Department of Agriculture National Agricultural Statistics Service, 2019, https://www.nass .usda.gov/Publications/Ag_Statistics/2017/ Chapter09.pdf (accessed 4 Apr. 2019).

Vogel, R.M., Yaindl, C., and Walter, M., 2011, Nonstationarity: Flood magnification and recurrence reduction factors in the United States: Journal of the American Water Resources Association, v. 47 , p. $464-474$, https://doi.org/10.1111/j. 1752 $-1688.2011 .00541 . x$.

Wallace, J.M., Held, I.M., Thompson, D.W., Trenberth, K.E., and Walsh, J.E., 2014, Global warming and winter weather: Science, v. 343, p. 729 730, https://doi.org/10.1126/science.343.6172.729.

Wolfram Alpha, 2019, Computational intelligence website: https://www.wolframalpha.com (accessed 21 Aug. 2019).

Woodward, F.I., 1987, Stomatal numbers are sensitive to increases in $\mathrm{CO}_{2}$ from pre-industrial levels: Nature, v. 327, p. 617-618, https://doi.org/ 10.1038/327617a0.

Yan, X.H., Boyer, T., Trenberth, K., Karl, T.R., Xie, S.-P., Nieves, V., Tung, K.-K., and Roemmich, D., 2016, The global warming hiatus: Slowdown or redistribution?: Earth's Future, v. 4, p. 472-482, https://doi.org/10.1002/2016EF000417.

ManUSCRIPT ReCEIVEd 8 Nov. 2019

ReVised MANUSCRIPT RECEIVED 15 Apr. 2020

MANUSCRIPT ACCEPTED 20 JuLY 2020 